\title{
オーケナイトのケイ酸イオンの構造と熱分解過程
}

\author{
岡田能彦・増田嗣也・石田秀輝*・西戸裕雨** \\ 小野田セメント(株)中央研究所, 285 千葉県佐倉市大作 2-4-2 \\ *(株)INAX 基礎研究所, 479 愛知県常滑市港町 3-77 \\ **岡山理科大学蒜山研究所，717-06 岡山県真庭郡川上村上福田 1201
}

\section{Silicate Anion Structure and Dehydration Processes of Okenite}

\author{
Yoshihiko OKADA, Tsuguya MASUDA, Hideki ISHIDA* and Hirotsugu NISHIDO** \\ Central Research Laboratory, ONODA Cement Co., Ltd., 2-4-2, Ohosaku, Sakura-shi, Chiba 285 \\ *Basic Research Center, INAX Corporation, 3-77, Minato-machi, Tokoname-shi, Aichi 479 \\ **Hiruzen Research Institute, Okayama University of Science, 1201, Kamihukuda, Kawakami-son, Maniwa-gun, Okayama 717-06
}

[Received March 1, 1994; Accepted July 21, 1994]

The sillicate anion structure and thermal decomposition behavior of okenite were studied mainly using solid ${ }^{29}$ Si NMR. The silicate anion structure of okenite is very close to some parts of the sheet structure of $\mathrm{gy}$ rolite. Dehydration occurs at around 119 and $315^{\circ} \mathrm{C}$ which are caused by the decomposition of the doublechain and sheet structure, and the sheet structure, respectivly. Although, the dehydration is caused by the water in the interlayer of okenite, and the main silicate anion structure remains untill around $350^{\circ} \mathrm{C}$. From 350 to $700^{\circ} \mathrm{C}$, the sillicate anion structure decompose gradually as the temperature increases and many kinds of sillicate anions are formed from the double-chain and the sheet structure of okenite. By the thermal treatment above $800^{\circ} \mathrm{C}$, wollastonite, pseudo-wollastonite and amorphous silica are formed and pseudo-wollastonite, cristobalite, quartz and silica glass are formed over $1200^{\circ} \mathrm{C}$.

Key-words: Calcium silicate hydrate, Okenite, Wollastonite, Pseudo-wollastonite, Dehydration, Decomposition, TG-DTA, ${ }^{29}$ Si NMR, Silicate anion

\section{1. 緒言}

オーケナイト (Okenite : $\left.\left(\mathrm{Ca}_{10}\left(\mathrm{Si}_{6} \mathrm{O}_{16}\right)\left(\mathrm{Si}_{6} \mathrm{O}_{15}\right)_{2} \cdot 18 \mathrm{H}_{2} \mathrm{O}\right)\right)$ は，天然鉱物として発見されている1) 3)ほかに Cole と Lancucki の報告による30年経過したダムのコンクリート から検出された報告4)があるものの合成された例は見当た らない5)

オーケナイトの結晶構造は, Merlinoによって複鎖状と シート状ケイ酸イオンで形成されているケイ酸カルシウム 水和物であることが示されている6)。 また熱特性に関する 研究として, Gard と Taylor が行ったインド産のオーケ ナイトでは， $730^{\circ} \mathrm{C} て ゙$ 脱水が起こり，ケイカイ石とクリス トバライトを生成することが報告されている7)。むた，6 種類のインド産のオーケナイトの熱分析とX線回折 (XRD) を行った, Phadke とKshirsagar の報告8)による と, $100^{\circ} \mathrm{C}$ で吸着水， $190,370^{\circ} \mathrm{C}$ で構造水の脱水があり，

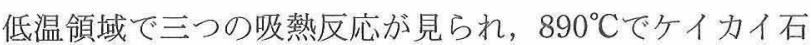

の生成に伴うシャープな発熱反応が認められるとしてい る。京た熱重量分析結果から算出した総脱水量は約 $17.5 \%$

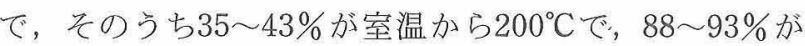
$500^{\circ} \mathrm{C}$ 以下で起こると報告されている。しかし，これらの 報告では，熱分解の過程での詳細な鉱物組成の変化及びこ れを構成するケイ酸イオンの挙動に関して触れられていな h.

ここでは，主に固体 ${ }^{29} \mathrm{Si}$ NMR を用いてオーケナイトを 形成するケイ酸イオンの構造及び加熱分解過程でのケイ酸 イオンの変化を追跡し，これまでの報告と異なる知見を得 たので報告する。

\section{2. 実験方法}

2.1 オーケナイト

オーケナイトは，これまで多くの研究に使用されてきた インド (Poona, Bombay) 産8)のものを用いた. 表 1 にそ の化学組成を示す。

\section{2 加熱処理}

TG-DTA の結果に基づき，100，150，250，350，500， $700,800,900,1000,1200^{\circ} \mathrm{C}$ 各温度で $1 \mathrm{~h}$ 時間加熱処理 した後，吸水，炭酸化を防止するために，モレキュラシー ブ $4 \mathrm{~A}$ を使用したデシケーター内に保存し，これを加熱 試料とした。

\section{3 評価方法}

加熱試料の相変化は XRD を用い，ケイ酸イオンの構造 変化は ${ }^{29} \mathrm{Si}$ NMR (Nuclear Magnetic Resonance) を用い， 結晶形熊の変化はFE-SEM（Field Emission-type Scanning Electron Microscopy) を用い検討した。

TG-DTA は，理学電機製のTAS200を用い，昇温速度 $10^{\circ} \mathrm{C} / \mathrm{min}$ で大気中で測定し，XRD は，理学電機製の

Table 1. Chemical Composition of Okenite from Poona (India)

\begin{tabular}{lllllllll}
\hline $\mathrm{SiO}_{2}$ & $\mathrm{Al}_{2} \mathrm{O}_{3}$ & $\mathrm{Fe}_{2} \mathrm{O}_{3}$ & $\mathrm{MgO}$ & $\mathrm{CaO}$ & $\mathrm{Na}_{2} \mathrm{O}$ & $\mathrm{K}_{2} \mathrm{O}$ & $\mathrm{H}_{2} \mathrm{O}$ & Total \\
55.8 & 0.18 & 0.00 & 0.00 & 27.57 & 0.69 & 0.14 & 16.01 & 100.39 \\
\hline
\end{tabular}


RINT1000型ディフラクトメータを用い, 電圧 $40 \mathrm{kV}$, 電 流40 mA で測定を行った.

NMR（日本電子製， GX-270 CPMAS Unit (NMGSH-27MU）を付加した装置）測定では， ${ }^{29} \mathrm{Si}$ 核観測周 波数 $53.55 \mathrm{MHz}$ ，出力 $400 \mathrm{~W}$, Proton 照射周波数 270.06 $\mathrm{MHz}$, 出力150 W にて MASGHD 法 (Magic Angle Spinning Gated Proton Decoupling Method) と CPMAS 法 (Cross Polarization Magic Angle Spinning Method) を用 い, 緩和時間 $\left(T_{1}\right): 6 \mu \mathrm{s}$, パルス delay time : $10 \mathrm{~s}$, 積算 回数10000回にて行った。種々の測定条件のばらつきの補 正（半定量によるケイ酸イオンの評価）9，10)とケミカルシ フトの補正のための内部標準物質として, シリコーンゴム の小片（0.1 mg）をサンプルセルの底面に固定して用い た.

FE-SEM（日立製作所製，S-4100 model）は，Pt-Pd スパッタリングした試料を加速電左 $10 \mathrm{kV}$, 試料電流 10-11Aの条件下で観察を行った。

比表面積の測定は，Micromeritics 社製 FlowSorb II 2300を用いて窒素ガスによる BET 表面積を求めた。

\section{3. 結果と考察}

\section{1 オーケナイト}

\section{1 .1 熱分析}

オーケナイトの熱分析結果を図 1 に示す.TGの減量の 総量は約 18 mass \%であり，200 $\mathrm{C}$ な゙で約 9 mass $\%$, $200 \sim 1000^{\circ} \mathrm{C}$ 範囲で約 9 mass\%であった。 またDTA で は, $83,119,164,266$ と $315^{\circ} \mathrm{C} の$ 五つの吸熱ピークがあり, $119^{\circ} \mathrm{C}$ を心とした低温側と $315^{\circ} \mathrm{C}$ 高温側の 2 段階の吸

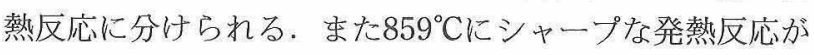
検出された。発熱反応温度とTGの総量は, Phadke と Kshirsagar の結果8) とほぼ一致したが，低温側と高温側の 二つの吸熱のパターンは類似して抢り，それぞれの吸熱

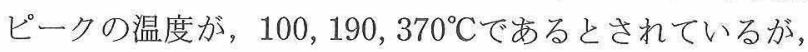
本研究では，それぞれ $60 \sim 70^{\circ} \mathrm{C}$ 程度低温側に倹出された。

\subsection{2 鉱物相}

表 2 に XRDの結果を Heller と Taylor の結果11) と対比 して示したが，主な回折線が一致しており，(001)面の良 く発達した純度の高いオーケトイトであると判断される。

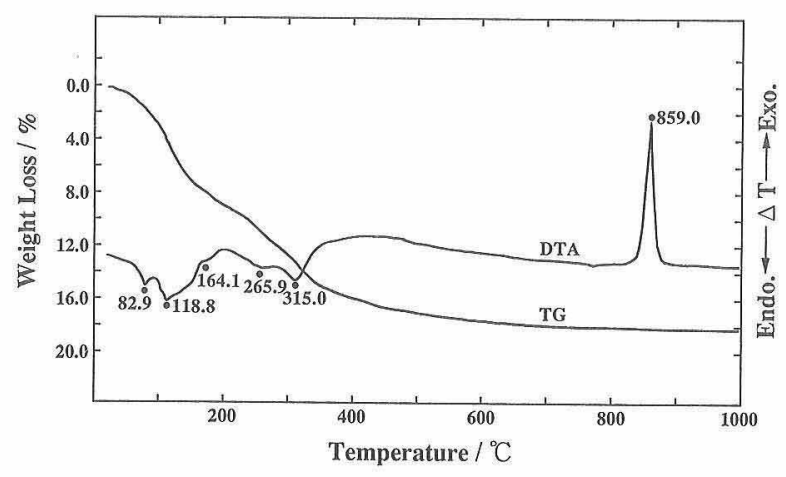

Fig. 1. TG-DTA curves of okenite.
Table 2. X-ray Diffraction Data for Okenite Comparison with Heller's Data ${ }^{11)}$ and Measured Data

\begin{tabular}{|c|c|c|c|}
\hline \multicolumn{2}{|c|}{ Heller's data "W } & \multicolumn{2}{|c|}{ measured data } \\
\hline $\mathrm{d} / \mathrm{nm}$ & $\mathrm{I} / \mathrm{I}_{0}$ & $\mathrm{~d} / \mathrm{nm}$ & $1 / . I_{0}$ \\
\hline 2.1 & 100 & 2. 132 & 100 \\
\hline 1.03 & 20 & 1.072 & 14 \\
\hline 0.88 & 80 & 0.885 & 5 \\
\hline 0.74 & 40 & 0.716 & 5 \\
\hline 0.68 & 20 & 0.675 & 1 \\
\hline 0.619 & 30 & 0.621 & 2 \\
\hline 0.579 & 10 & 0.579 & 1 \\
\hline 0.522 & 30 & 0.537 & 12 \\
\hline 0.442 & 30 & 0.442 & 1 \\
\hline 0.427 & 10 & 0.429 & 4 \\
\hline 0.408 & 20 & 0.416 & 2 \\
\hline 0.390 & 20 & 0.396 & 1 \\
\hline 0.356 & 80 & 0.358 & 17 \\
\hline 0.334 & 10 & 0.321 & 2 \\
\hline 0.322 & 10 & 0.310 & 5 \\
\hline 0.307 & 60 & 0.307 & 18 \\
\hline 0.305 & 60 & 0.300 & 3 \\
\hline 0.298 & 50 & 0.295 & 4 \\
\hline 0.293 & 80 & 0.292 & 3 \\
\hline 0.280 & 30 & 0.281 & 4 \\
\hline 0.277 & 50 & 0.273 & 3 \\
\hline 0.268 & 20 & 0.268 & 4 \\
\hline 0.253 & 30 & 0.255 & 2 \\
\hline
\end{tabular}

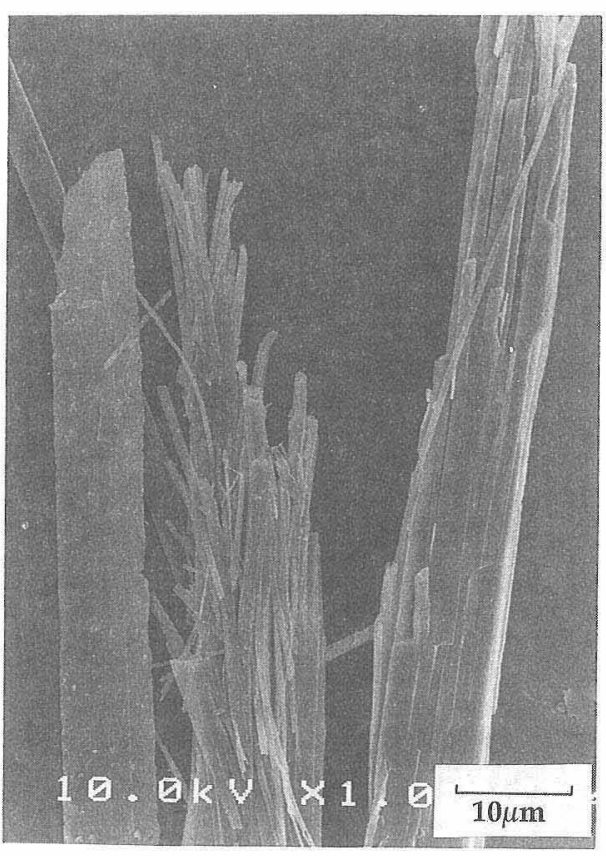

Fig. 2. FE-SEM photograph of okenite.

\subsection{3 電子顕微鏡観察 (FE-SEM)}

図 2 に加熱前の試料の FE-SEM 像を示した、オーケナ イト結晶は, 径が約 $0.1 \sim 1.0 \mu \mathrm{m}$, 長さが約 $400 \mu \mathrm{m}$ の結 晶からなっており (写真中央)，この集合体が角板状の結 


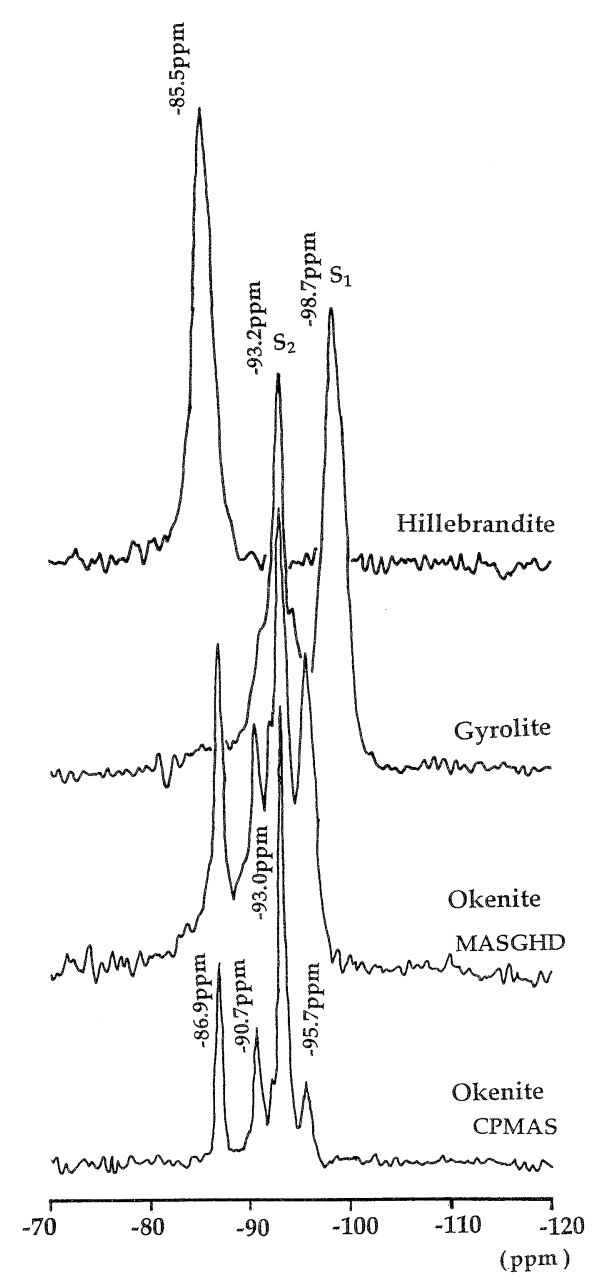

Fig. 3. ${ }^{29} \mathrm{Si}$ NMR spectra for okenite and other reference (hillebrandite and gyrolite)

$S_{1}$ and $S_{2}$ on gyrolite: names of sheet silicate structure by Merlino. ${ }^{14)}$

晶（写真右）又は，径約 $10 \mu \mathrm{m}$ ，長さ数 $\mathrm{mm}$ の針状又は 棒状結晶（写真左）を呈する。

\section{1 .4 固体 NMR}

図 3 に CP-MAS 及び MASGHD - ${ }^{29} \mathrm{Si}$ NMR のスペク トルを示した。図には鎖構造のケイ酸カルシウム水和物と して比較のためにヒレブランダイト ${ }^{12)}$, シート構造のも のとしてジャイロライト10)のスペクトルを併記した.

オーケナイトはー86.9, - 90.7, - 93.0, $-95.7 \mathrm{ppm}$ にシ グナルを持ち， $Q^{2}$ (鎖構造ケイ酸イオン) と $Q^{3}$ (枝分か れ構造ケイ酸イオン) に帰属される13).

$-86.9 \mathrm{ppm}$ のシグナルは，併記したヒレブランダイト の $Q^{2}$ に比較して水素核の影響と考えられる $2.0 \mathrm{ppm}$ 程度 シフトしているが， $Q^{2}$ のグループに含まれ鎖構造と考え られる。なたー90.7, $-93.0,-95.7 \mathrm{ppm}$ のシグナルは， $Q^{3}$ (枝分かれケイ酸イオン) に含まれる.これらの帰属 は, カルシウムイオン, シラノ一ル基, 水分子等の影響を 受けていることが考えられるが, 帰属は非常に困難であ り，ここでは， $Q^{3}-1, Q^{3}-2, Q^{3}-3$ と略記することとした。

オーケナイトの $Q^{3}$ は, 2 種類のシート構造（ $S_{1}$ 層と $S_{2}$
層)10),14)からなるジャイロライトの $S_{2}$ 層と類似しており, これはオーケナイトのケイ酸イオンの構造が, 複鎖とシー トからなる構造とする Merlino の報告6) と一致する。

CP-MAS 法 ${ }^{15)}$ とMASGHD 法のスペクトルを比較する と, すべてのシグナルのケミカルシフト值が一致すること から，オーケナイトを構成しているケイ酸イオンはすべて 水素化されたシラノ一ル, もしくは, 近傍の水素核と相互 作用を持つケイ酸イオンであることを示している。

\section{2 加熱分解過程}

\section{2 .1 相の変化}

図 4 に加熱処理後の XRD の変化を示した.オーケナイ トのシャープな回折線のほとんどは $100 \sim 150^{\circ} \mathrm{C}$ 間でブ ロードとなり， $250^{\circ} \mathrm{C}$ では消滅した.

加熱処理前の試料で見られた $(001)$ 面の非常に強い底面 反射 $(d=2.1 \mathrm{~nm})$ の回折線は, 処理温度の上昇とともに $700^{\circ} \mathrm{C}$ 付近まで連続的に高角度側へシフトし, 層間収縮が 起きていることを示した。このときの総シフト幅は約 $0.54 \mathrm{~nm}$ であった. 250〜 $500^{\circ} \mathrm{C}$ の間で $0.558,0.363,0.334$ $\mathrm{nm}$ の新たな回折線が出現し, Gard と Taylor ${ }^{7)}$ は, これ を発生期のケイカイ石（oriented wollastnite）であると述 べているようであるが, $250,350,500^{\circ} \mathrm{C}$ 試料では，そ れぞれ数本の回折線が検出され, それぞれの回折位置が異

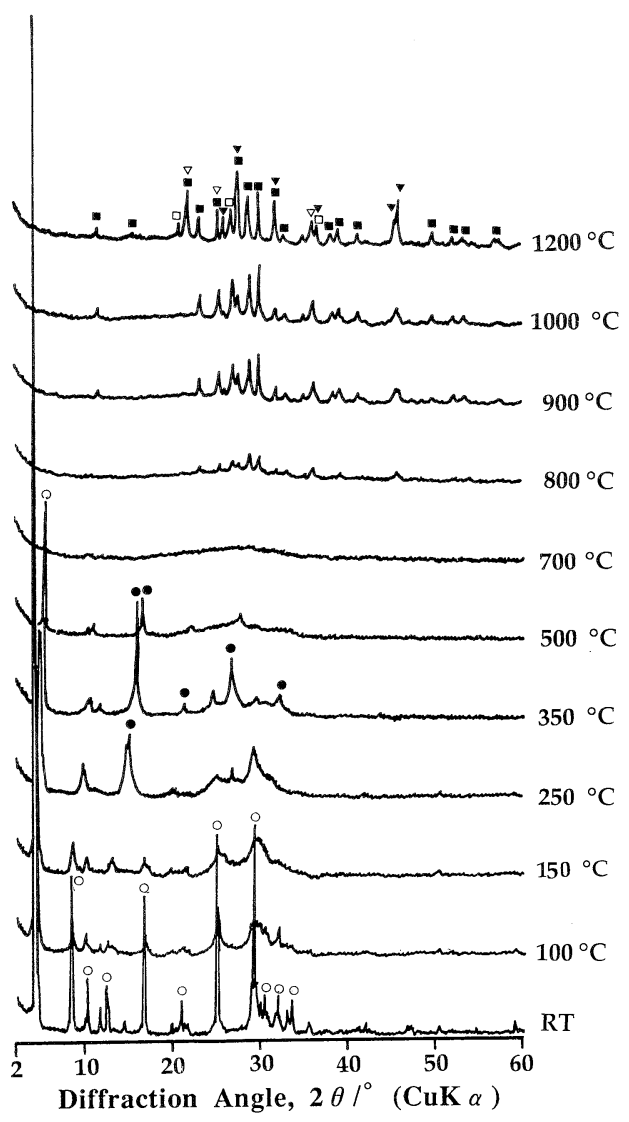

Fig. 4. XRD patterns of heated specimens for okenite. The symbols represent as follows:

$\bigcirc$ okenite, wollastonite, $\boldsymbol{\nabla}$ pseudo-wollastonite, $\nabla$ cristobalite, $\square$ quartz, $\bigcirc$ unknown material. 
なり，同一の物質とは考えられず同定には至らなかった。

$700^{\circ} \mathrm{C}$ 加熱では, オーケナイトの強い回折線の一部が 検出されるものの他の回折線はすべて消失した。 $800^{\circ} \mathrm{CW}$ 上では，ケイカイ石（JCPDS カード27-106416)）の回折

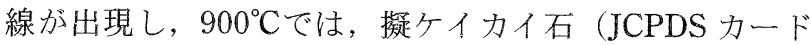
31-30017)）も出現し，加熱処理温度の上昇とともに回折 強度は上昇し, 結晶化が進行していることを示した。 $1200^{\circ} \mathrm{C}$ では，ケイカイ石の回折線は消隇し，擬ケイカイ 石, クリストバライト，石英の回折線のみが検出された. 擬ケイカイ石及び石英の生成はこれまで報告(6) 8)されて いないが XRD と次節で述べる NMRの結果から，これら の存在は明らかである。

\subsection{2 ケイ酸イオンの変化}

図 5 に加熱試料の ${ }^{29} \mathrm{Si} N \mathrm{NR}$ スペクトルを示した。 MASGHD 法とCPMAS 法のスペクトルともに，加熱前 の試料では 4 本に分離していた $Q^{2}, Q^{3}$ のシグナルが，加

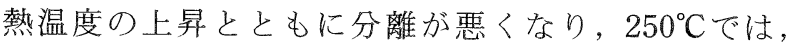
$-87.4 \mathrm{ppm}$ とー93.4 ppmの 2 本のシグナルとなった。 たー109.5 ppm のシグナルは, 加熱温度の上昇とともにシ
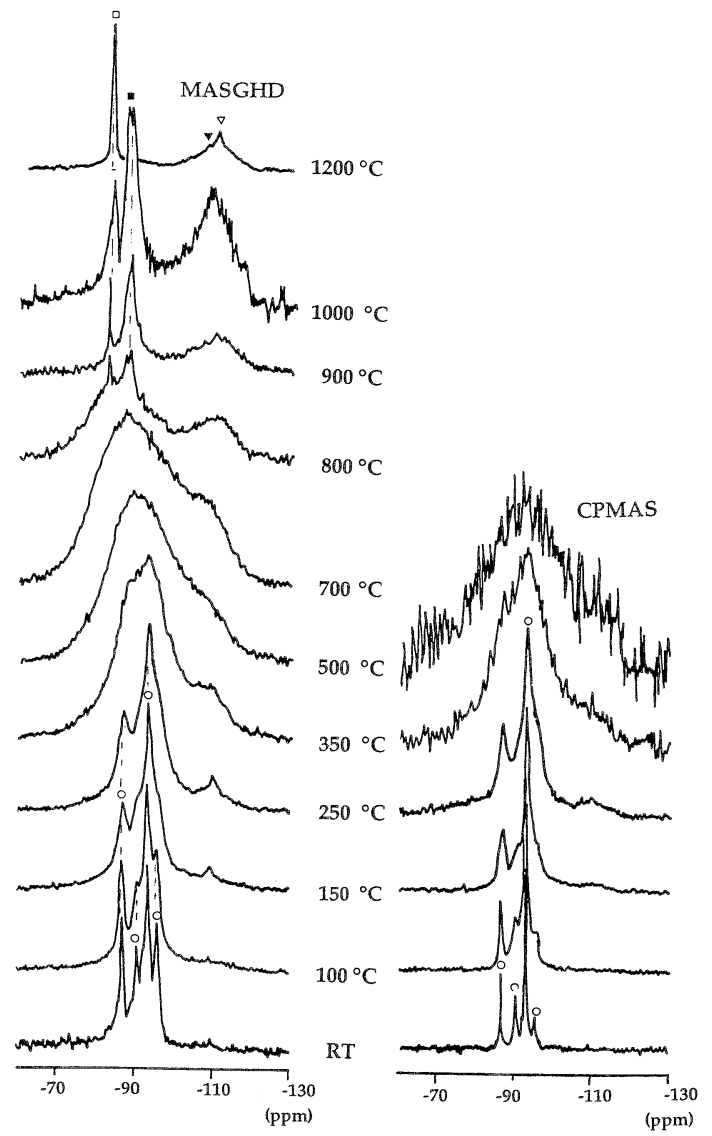

Fig. 5. MASGHD and CPMAS ${ }^{29} \mathrm{Si}$ NMR spectra of preheated specimens for okenite.

The symbols represent as follows:

okenite $(-86.9,-90.7,-93.0,-95.7 \mathrm{ppm})$,

wollastonite $(-87.2,-88.6 \mathrm{ppm})$,

$\square$ pseudo-wollastonite ( $-82.9 \mathrm{ppm})$,

quartz (-107.0 ppm),

$\nabla$ cristobalite $(-109.0 \mathrm{ppm})$.

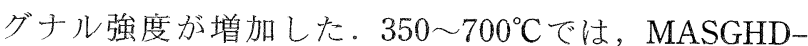
NMR シグナルは，約 $-90 \mathrm{ppm}$ を心としたー75〜 - $115 \mathrm{ppm}$ の幅の広いブロードなシグナルへ变化したの に対して, CPMAS 法のスペクトルは，500ㄷ上でノィ ズが大きくシグナルは検出されなかった。このことは， オーケナイトの複鎖とシート状のケイ酸イオンが $350^{\circ} \mathrm{C} 以$ 上で徐々に熱分解を受け，特に $500^{\circ} \mathrm{C}$ 以上では，水素核上 関連（シラノ一ル基，水の水素結合等）のない $Q^{1} \sim Q^{4}$ の 種々のケイ酸イオンが生成したものと考えられる。

$800^{\circ} \mathrm{C}$ 以上では，ブロードなシグナルの中から -82.9 $\mathrm{ppm}$ と-88.6 ppmの $Q^{2}$ に相当するシグナル及び -110 $\mathrm{ppm}$ 付近にはブロードな $Q^{4}$ に相当するシグナルが検出さ れた。これらは，ケイカイ石 $(-88.6 \mathrm{ppm})^{18)}$ と擬ケイカ イ石 $(-82.9 \mathrm{ppm})^{18)}$ 及び，非晶質シリカ $(-110 \mathrm{ppm})$ に相当すると考えられる。

$1200^{\circ} \mathrm{C}$ では， $-82.9 \mathrm{ppm}$ の擬ケイカイ石と $-107 \mathrm{ppm}$ の石英 ${ }^{18)}$ ，-110 ppmのクリストバライト18)及びブロード な $Q^{4}$ シグナル（抢そらくシリカガラスであろう）が検出 された。これらの生成物はXRDの結果と一致した。

図 6 に，出発物質及び各温度で加熱処理した試料の NMR シグナル $\left(Q^{2}, Q^{3}-1, Q^{3}-2, Q^{3}-3, Q^{4}\right)$ の強度の変化を 示した。 TGにおいて $100^{\circ} \mathrm{C}$ 付近の低温側の脱水に相当す る温度領域では， $Q^{2}$ 及び $Q^{3}-1, Q^{3}-2, Q^{3}-3$ の 4 本のシグナ 儿強度は, 同程度の勾配で減少し, $315^{\circ} \mathrm{C}$ 付近の高温度側 では， $Q^{3}-2$ のシグナルのみが大きな減少を示した。つま り, TG が示した $83,119,164^{\circ} \mathrm{C}$ の低温度側の脱水では, 複鎖構造とシート構造の全体から脱水が起こり， $315^{\circ} \mathrm{C}$

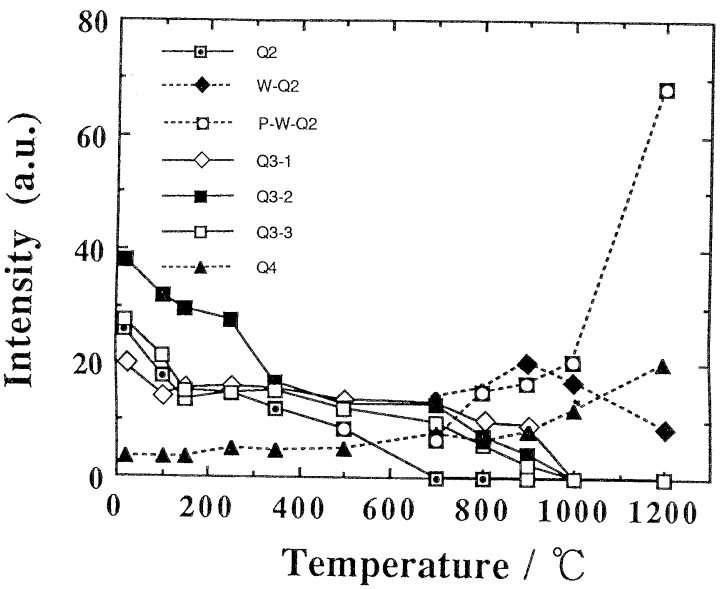

Fig. 6. Intensities of NMR signals assigned to silicate anions at various temperatures.

The symbols represent as follows:

$Q^{2}$ : Chain silicate structure of okenite $(-86.9 \mathrm{ppm})$, $\mathrm{W}-Q^{2}$ : Chain silicate structure of wollastonite $(-88.6 \mathrm{ppm})$, $\mathrm{P}-\mathrm{W}-\mathrm{Q}^{2}$ : Cyclic chain silicate structure of pseudo-wollastonite $(-82.9 \mathrm{ppm})$,

$Q^{3}-1$ : Sheet silicate structure of okenite $(-90.7 \mathrm{ppm})$, $Q^{3}-2$ : Sheet silicate structure of okenite $(-93.0 \mathrm{ppm})$, $Q^{3}-3$ : Sheet silicate structure of okenite $(-95.7 \mathrm{ppm})$,

$Q^{4}$ : Three-dimensional silicate structure of cristobalite $(-109.0$ ppm). 
主とした高温度側 $\left(266,315^{\circ} \mathrm{C}\right)$ の脱水では，シート構造 $\left(Q^{3}\right)$ の一部と相互関係にある水が解離したと考えられ る。

このことは, Phadke と Kshirsagar 脱水過程を吸着水 と構造水に分けて論じているように年，異なった構造から の脱水であると考えられる。しかし，NMR から導かれた これらの結果が吸着水と構造水の違いに起因したものかど うかについては更に検討が必要である。

500 700 Cの範囲では， NMR スペクトルはブロードで あるために詳しい解析はできないが，オーケナイトを構成

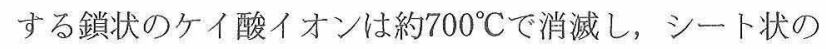
ケイ酸イオンは $1000^{\circ} \mathrm{C}$ 付近で消減している.

熱分解生成物であるケイカイ石々擬ケイカイ石の生成開 始温度の推定も困難であるが， $700^{\circ} \mathrm{C}$ 付近のブロードなシ

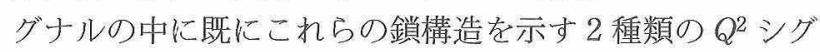
ナルが含まれていると思われる。

図6に示したシグナル強度の变化では， $700^{\circ} \mathrm{C}$ 付近で オーケナイトの $Q^{2}$ の消滅と同時にケイカイ石の $Q^{2}$ (-88.6 ppm) が生成し， $900^{\circ} \mathrm{C}$ 亦で增加した。字た $1000^{\circ} \mathrm{C}$ 付近でオーケナイトの $Q^{3}$ が消隇し，擬ケイカイ石 (環状 $Q^{2}:-82.9 \mathrm{ppm}$ ) が急増する.このことは，加熱分 解前のケイ酸イオンの構造が, 分解後のケイ酸イオンの構 造と関係があることを示唆していると考えられ，複鎖構造 とシート構造のケイ酸イオンで構成されているオーケナイ トは，加熱により鎖構造とシート構造の個々の構造へ変化 したと推定される。

$700^{\circ} \mathrm{C}$ で確認できた $Q^{2}$ (ケイカイ石)は $900^{\circ} \mathrm{Cをピークに}$ シグナル強度は低下し，これと相反して高温安定相である 擬アイカイ石は，加熱温度の上昇とともにシグナル強度が 増加した.このことは, ケイカイ石が擬ケイカイ石へ転移

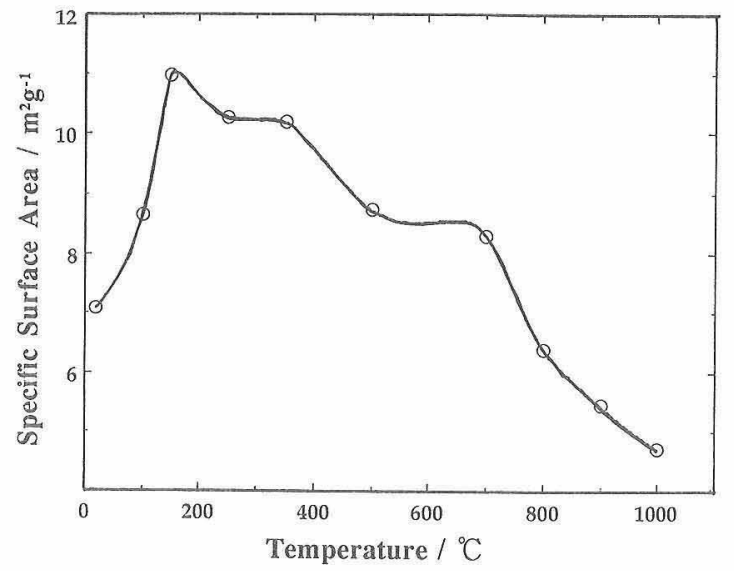

Fig. 7. The specific surface areas (BET) for okenite as a function of temperatures.

していることを示している。

熱分解の過程で生じた余剩のケイ酸は，NMR では $Q^{4}$ (-105〜-114 ppm) として検出され，図6に示すよう

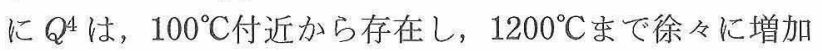
している. 特に $150^{\circ} \mathrm{C}$ 以上で $Q^{4}$ のシグナルが明瞭になる ことから初期の吸熱反応は脱水だげはなく, 脱水に伴い 非晶質のケイ酸イオンも生成されている可能性がある.

\subsection{3 表面積及び形状の変化}

図 7 に加熱処理試料の BET 比表面積を示した。未処理 のものは, 約 $7 \mathrm{~m}^{2} / \mathrm{g}$ であり, 低温側の脱水が終了するま で増加し， $150^{\circ} \mathrm{C} て ゙$ 約 $11 \mathrm{~m}^{2} / \mathrm{g}$ となる. その後も DTAの 結果に対応して $350^{\circ} \mathrm{C}$ 付近と $700^{\circ} \mathrm{C}$ 付近に変曲点を持ち, $1000^{\circ} \mathrm{C}$ で約 $4.5 \mathrm{~m}^{2} / \mathrm{g}$ まで低下した。

図 8 に加熱前の試料及び $100,350,700,1000^{\circ} \mathrm{C}$ 各温度
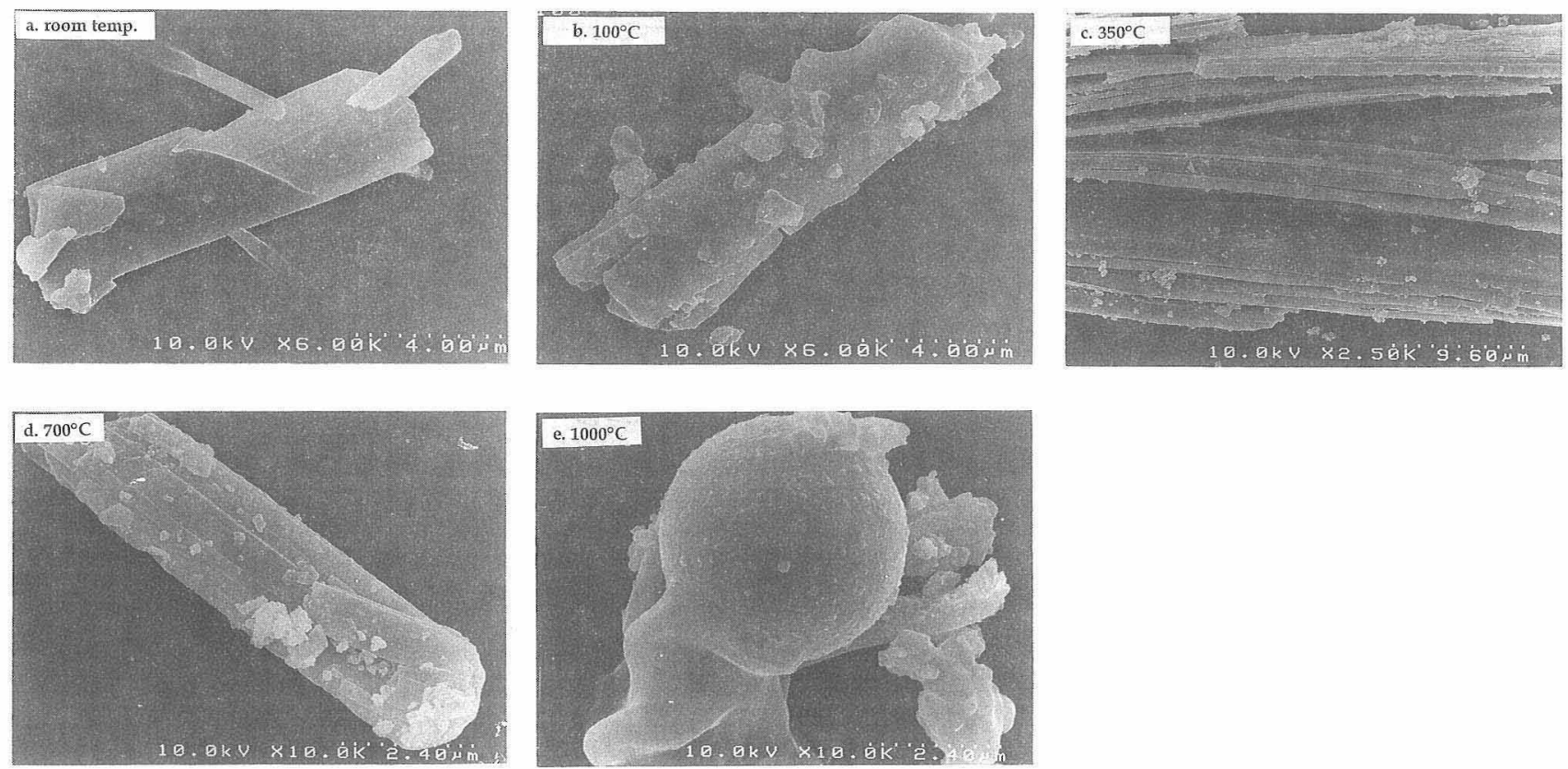

Fig. 8. FE-SEM photographs of preheated specimens for okenite (a) room temp., (b) $100^{\circ} \mathrm{C}$, (c) $350^{\circ} \mathrm{C}$, (d) $700^{\circ} \mathrm{C}$, (e) $1000^{\circ} \mathrm{C}$. 
で処理した試料の FE-SEM 像を図 8 (a)〜 (e)に示した。 加熱前の試料では長さ $10 \mu \mathrm{m}$, 径 $2 \mu \mathrm{m}$ 程度の棒状の結晶 と径が $0.5 \mu \mathrm{m}$, 長さ数 $\mu \mathrm{m}$ の針状の結晶が数多く観察さ れたが， $100^{\circ} \mathrm{C}$ 試料では，針状結晶が崩壊したものと思 われる約 $1 \mu \mathrm{m}$ 程度の不定形の物質と加熱前の試料と同様 に10 $\mu \mathrm{m}$ 程度の棒状結晶が観察される。この段階で針状 結晶が崩れ，不定形の微細なものが生成したことと棒状の 結晶に亀裂が生じたことにより比表面積が増加したものと 考えられる。

図 8 (c)には, 針状の結晶が集合化した板状の結晶を $350^{\circ} \mathrm{C}$ で加熱処理したものを示した。積層されていた板状 結晶に歪みが生じ，剝離していることを示している。 $700 \sim 1000^{\circ} \mathrm{C}$ 加熱（図 8 (d)) では，加熱前の試料の外形 状に類似した棒状結晶の表面に板状の結晶が成長し， $1200^{\circ} \mathrm{C}$ の加熱処理したものも同様の形状をしていること からケイカイ石であると推定される。 また $1000^{\circ} \mathrm{C}$ 以上の 加熱処理した試料の一部に球状の溶融体がみられる（図 $8(\mathrm{e}))$.これは，オーケナイトに含まれている $\mathrm{Al}_{2} \mathrm{O}_{3}$, $\mathrm{Na}_{2} \mathrm{O}$ 等の不純物と熱分解で生成した遊離ケイ酸が反応し てシリカガラスを生成したものと考えられる.

\section{4. まとめ}

（1）オーケナイトのケイ酸イオンの構造は，複鎖状と ジャイロライトの $S_{2}$ 層と類似したシート状から成る複合 構造である。

（2）オーケナイトの層間収縮は，約 $100^{\circ} \mathrm{C}$ 程度で始ま り $700^{\circ} \mathrm{C}$ 程度まで徐々に進行する。

（3）ケイ酸イオンの構造変化は全温度領域で起こる が，特に $320^{\circ} \mathrm{C}$ 以下の脱水は， $119^{\circ} \mathrm{C}$ 低温度側で複鎖構 造とシート構造からの脱水が関与し, $315^{\circ} \mathrm{C}$ 付近の高温度 側でシート構造からの脱水がケイ酸イオンの構造変化に関 与している。

(4) $350 \sim 700^{\circ} \mathrm{C}$ 間では，鎖構造 $\left(Q^{2}\right)$ を中心に種々 のケイ酸イオン（モノマー〜高次構造のケイ酸イオン）が
生成した。

（5） $800^{\circ} \mathrm{C}$ 以上の加熱処理で擬ケイカイ石とケイカイ 石が同時に生成するが，これは加熱前の構造（複鎖構造と シート構造）の影響を受けて複鎖構造はケイカイ石（単鎖 構造）に，シート構造は擬ケイカイ石（環状構造）へ分解 されると考えられる。

（6） $1200^{\circ} \mathrm{C}$ 加熱処理で，擬ケイカイ石，クリストバ ライト，石英，シリカガラスを生成する.

\section{文献}

1) A. S. Eakle, Univ. Calif. Bull. Dept. Geol., 10, 327-60 (1917)

2) S. Gross, GSI Bull., 70, 45 (1977).

3）西戸裕嗣，坂本尚史，大塚良平，日本鉱物学会昭和 58 年度 年会講演要旨集 (1983) p. 126.

4) W. F. Cole and C. J. Lancucki, Cem. Concr. Res., 13, 611-18 (1983)

5) E. P. Flint, H. F. Mcmurdie and L. S. Wells, J. Res. Nat. Bureau of Standards, 21, 617-38 (1938).

6) S. Merlino, Am. Mineral., 68, 624-26 (1983).

7) J. A. Gard and H. F. W. Taylor, Mineral. Mag., 31, 5-20 (1956).

8) A. V. Phadke and L. K. Kshirsagar, Mineral. Mag., 43, 677-78 (1980)

9）岡田能彦，水野聡浩，光田 武，日本化学会第61春季年会 要旨集, 3F1-45 (1990)

10）岡田能彦, 方 永浩, 石田秀輝, 西戸裕嗣, J.Ceram. Soc. Japan, 102, 449-55 (1994).

11) L. Heller and H.F.W. Taylor, Crystallographic Data for the Calcium Silicate, London, HMSO (1956) p. 22.

12) Y. Okada, K. Sasaki, H. Ishida and T. Mitsuda, "Ceramic Transactions, Vol. 37”, Am. Ceram. Soc. (1993) pp. 11-20.

13) W. Wieker, A.-R. Grimmer, A. Winkler, M. Magi, M. Tarmak and E. Lippmaa, Cem. Concr. Res., 12, 333-39 (1982).

14) S. Merlino, Mineral. Mag., 52, 377-87 (1988).

15) A. Pines, M. G. Gibby and J. S. Waugh, J. Chem. Phys., 59, 569-90 (1973).

16) H. Matsueda, Mineral. J., 7, 180-201 (1973).

17) L. Heller and H. F. W. Taylor, Crystallographic Data for the Calcium Silicate, London, HMSO (1956) p. 3.

18) N. Janes and E. Oldfield, J. Am. Chem. Soc., 107, 6769-75 (1985). 